\title{
Adenium obesum as a new potted flower: growth management ${ }^{(1)}$
}

\author{
RONAN CARLOS COLOMBO(2)*, MARIA APARECIDA DA CRUZ(2), DEIVED UILIAN DE CARVALHO(2), RODRIGO \\ THIBES HOSHINO(2), GUILHERME AUGUSTO CITO ALVES ${ }^{(2)}$, RICARDO TADEU DE FARIA(2)
}

\begin{abstract}
Adenium obesum, also known as desert rose, has recently become popular in Brazil, due to its exuberance and sculptural shape. However, the production of the species in commercial scale has been facing challenges regarding propagation of hybrids by in vitro cultivation techniques, potting medium composition, irrigation and fertilization management, disease and pest control. Unlike other species sold as potted plants, there are no commercial production protocols established for Adenium, mainly due to the scarcity of technical information about this species. Thus, this technical article aimed to provide information related to the Adenium growth, in view of its commercial scale production. In addition, aspects related to floral morphology, pollination and seed production of the species, as well as, vegetative propagation strategies were discussed.
\end{abstract}

Keywords: commercialization, desert rose, nutrition, potting medium, propagation.

\section{RESUMO}

Adenium obesum como nova flor de vaso: manejo cultural

Adenium obesum, também conhecida vulgarmente como rosa-do-deserto, tem se popularizado no Brasil nos últimos anos devido à sua exuberância e forma escultural. Porém, a produção da espécie em escala comercial tem enfrentado desafios em relação à propagação de seus híbridos por técnicas de cultivo in vitro, escolha de substratos, manejo da irrigação e fertilização, controle de doenças e pragas, dentre outros. Diferente de outras espécies comercializadas como planta de vaso, ainda não existem protocolos de produção comercial totalmente estabelecidos para Adenium, devido, principalmente, à escassez de informação técnica sobre a espécie. Assim, esse artigo técnico teve o intuito de trazer à luz da literatura algumas informações relacionadas ao cultivo da espécie, tendo em vista a sua produção em escala comercial. Além disso, abordou-se aspectos da morfologia floral, polinização e produção de sementes da espécie, bem como estratégias de propagação vegetativa.

Palavras chave: rosa-do-deserto, propagação, nutrição, substratos, comercialização.

\section{INTRODUCTION}

Adenium genus belongs to Apocynaceae, which includes many tropical ornamental species such as Catharanthus spp., Beaumontia spp., Carissa spp., Allamanda spp., Mandevilla spp., Nerium spp. and Plumeria spp. (COLOMBO et al., 2015). In this genus only one species is reported, i.e. Adenium obesum, firstly classified as Nerium obesum (fat oleander).

A. obesum (Forssk.) Roem. \& Schult. is found in the subSaharan region of Africa, from Sudan to Kenya and west of Senegal to south of Natal and Swaziland. Some authors divided $A$. obesum in subspecies or botanical varieties (PLAIZIER, 1980; FORSTER, 1998; HARGREAVES, 2002). However, in horticulture it was adopted to divide the Adenium genus into comprising 11 species: A. oleifolium,
A. swazicum, A. boehmianum, A. multiflorum, A. obesum, A. somalense 'Nova' (Tanzania), A. somalense, A. crispum, A. socotranum, $A$. arabicum and $A$. Oman (DIMMITT et al., 2009).

Adeniums can be grouped in herbaceous, shrub and arboreal plants, with succulent stems and roots. Many species are caudiciforms or paquicaules, which develop swollen roots and/or stems that act as primary organs for water reserves. The flowers have five sepals and five petals, in different colors, fused to a floral tube; the tube inner surface may have five or 15 red lines, called as nectar guides (Figure 1). The five stamens are cone-shaped and the anthers have their slits facing the inside of that cone. The anther tails protrude from the cone apex appear to be the true anthers. The stigma is hidden inside the cone formed by the anthers, just below them (DIMMITT et al., 2009). 


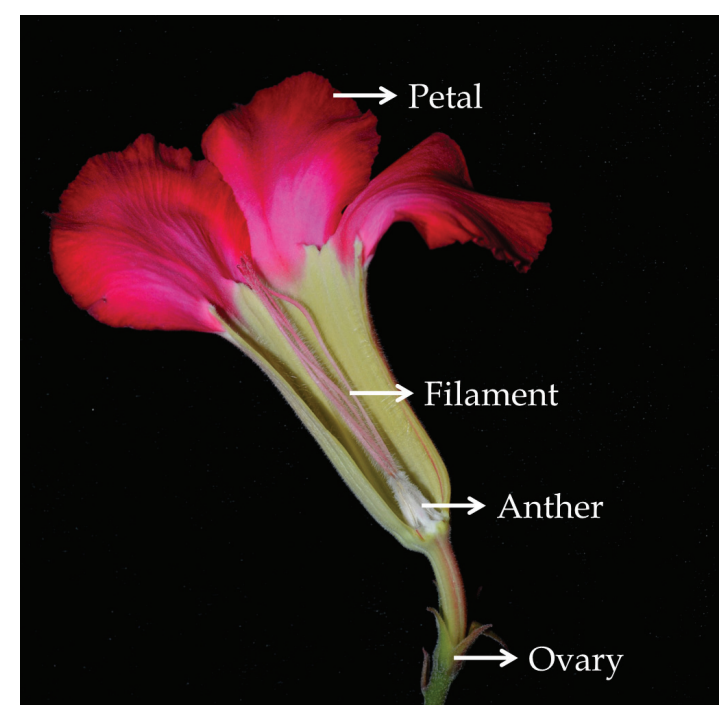

Figure 1. Floral morphology of $A$. obesum.

The fruits are formed in pairs after pollination and classified as follicles (Figure 2); when mature, they open longitudinally for release of the seeds (DIMMITT et al., 2009). However, not all plants produce seeds under cultivation conditions, since pollination is often unsuccessful due to male or female sterility
(McLAUGHLIN and GAROFALO, 2002). The sexual propagation is important, especially for the breeding programs for the species, due to the great morphological variability observed in the progeny resultant from a single crossing; as well as, for the production of rootstocks.

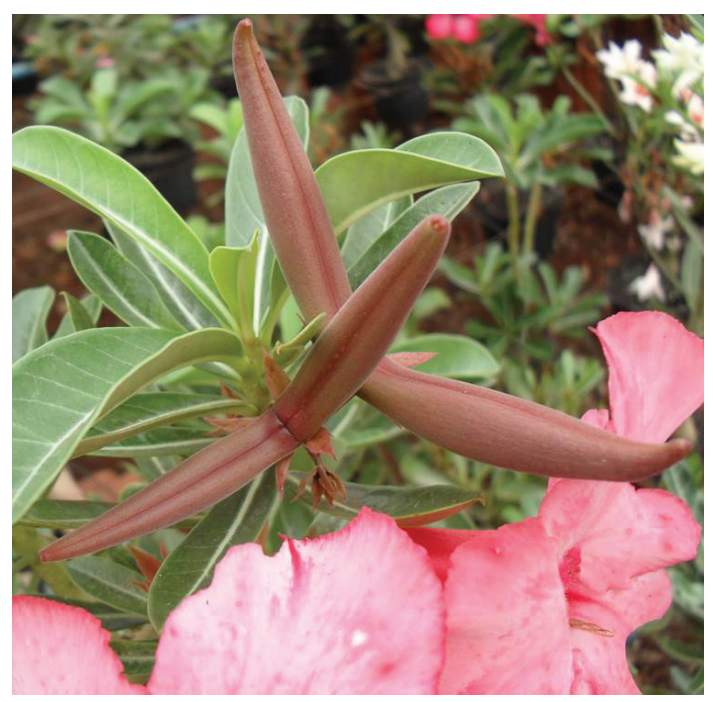

Figure 2. Fruits of $A$. obesum in development phase, 40 days after pollination.

Despite the great ornamental and commercial value, this species is known in Brazil for the last two decades and its commercial exploitation is recent. Thus, only limited information about commercial production of Adenium is available in the literature, as until recently, adeniums were considered a collector plant.

Thus, the present study aimed to describe the main aspects related to the commercial production of Adenium in Brazil, such as seed production and propagation, growing conditions and commercialization.

\section{ADENIUM PROPAGATION}

\section{Seed propagation}

A. obesum propagation is performed mainly by seeds, since the plants originating from seeds exhibit more swollen caudex and primary roots than those propagated from cuttings (COLOMBO et al., 2015).

The seed formation occurs by self-pollination or cross-pollination. The manual pollination is carried out taking off one or two petals from the receiving flower, to 
expose the anthers. Next, the anthers must be removed using a tweezer to collect the pollen grains, which are transferred to stigma from the receiving flower (Figure
3 A-D). After 90 days of flower pollination, the follicle starts dehiscence and the seeds can be collected for sowing.

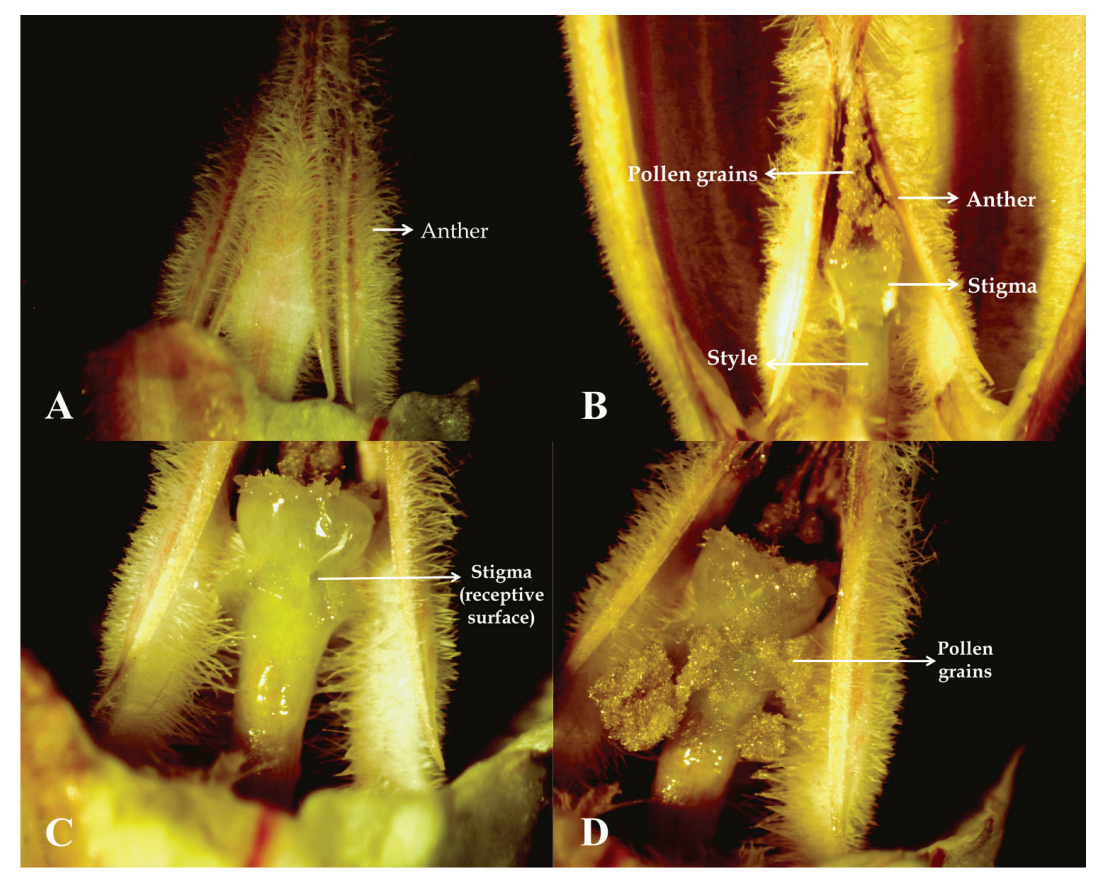

Figure 3. Details of $A$. obesum pollination: cone shaped by anthers protecting the stigma (A), exposure of stigma and pollen grains after anthers removal (B), detail of receptive surface in the stigma (C), and pollen grains released to stigma, effective pollination (D).

According to Colombo et al. (2015) the A. obesum follicles may present measures varying between 15.1 to $25.1 \mathrm{~cm}$ for length and 11.1 to 15.5 for central diameter, with the number of seeds varying from 28 to 118 seeds per follicle.
The seeds exhibit a cylindrical shape, brown staining integument and brown gold pappus (bristles) on both extremities, which helps dispersion by wind (Figure 4). $A$. obesum seeds are similar to the ones in oleander (Nerium oleander), but in this species bristles are on only one extremity (COLOMBO et al., 2015).

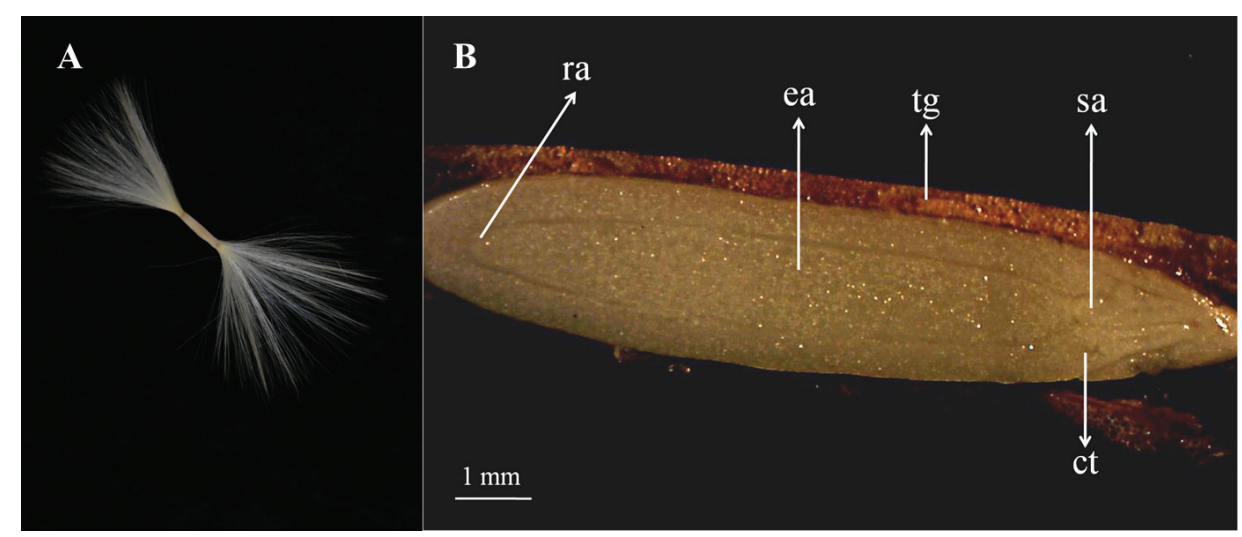

Figure 4. Morphological characterization of A. obesum seed, external (A) and internal (B) aspects: tg - tegument; ea - embryonic axis; ra - root apex; sa - stem apex; ct - cotyledons. Adapted from Colombo et al. (2015). 
Seed germination is commonly performed in different substrates, which are chosen according to the local availability of material. Substrates based on semi-composted pine bark employed for germination of $A$. obesum seeds, providing emergence rates $>93 \%$ (COLOMBO et al., 2017). These results corroborate to those observed in germination tests that were conducted in laboratories, confirming the elevated germination potential of this species (COLOMBO et al., 2015; COLOMBO et al., 2017).

In contrast, substrates presenting high water retention capacity, if handled incorrectly, can decrease the seedlings emergence due to seed rot. Colombo et al. (2017) observed that the A. obesum emergence in coconut fiber + sand was $83 \%$, while the mixture of coconut fiber + semi-composted pine bark provided $98 \%$ of emergence. Thereby, the importance to select the adequate mixture to be used as substrate was confirmed.

Another choice to germinate Adenium seeds is to employ commercial mixtures as Carolina Soil II substrate (Grow Plant, Brazil), in which the seedlings emergence can reach values close to $100 \%$ (Figure 5).

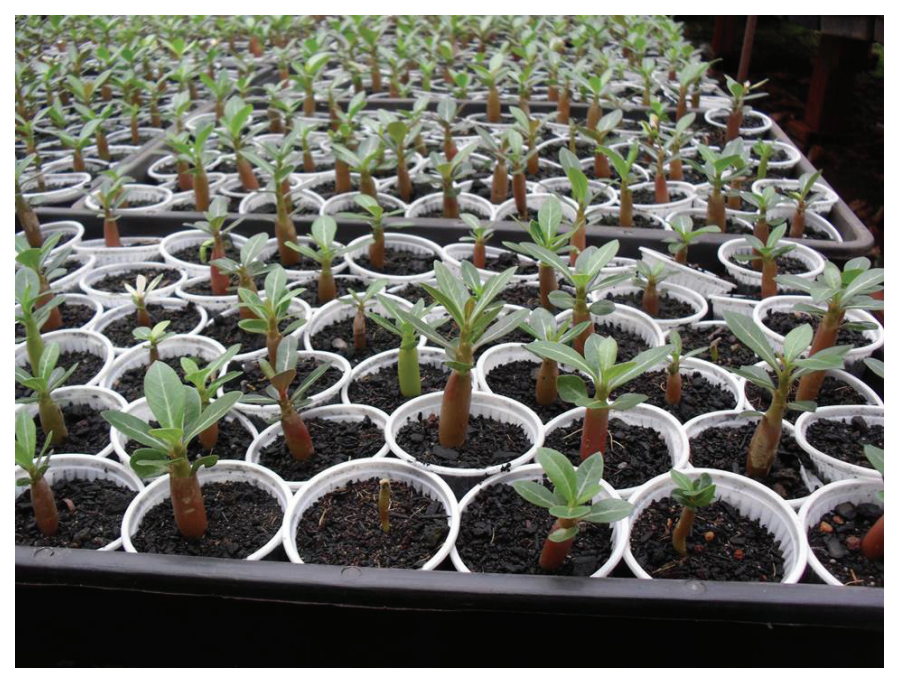

Figure 5. Germination of A. obesum seeds in semi-composted pine bark + turf.

\section{Cuttings propagation}

All commercially available Adenium material is the result of hybridization and has a high segregation rate when propagated by seeds, especially, cultivars with folded flowers. Thus, the Adenium vegetative propagation has been outstanding due to the maintenance of the cultivar characteristics. Propagation by cutting (Figure 6) and grafting are the most common.

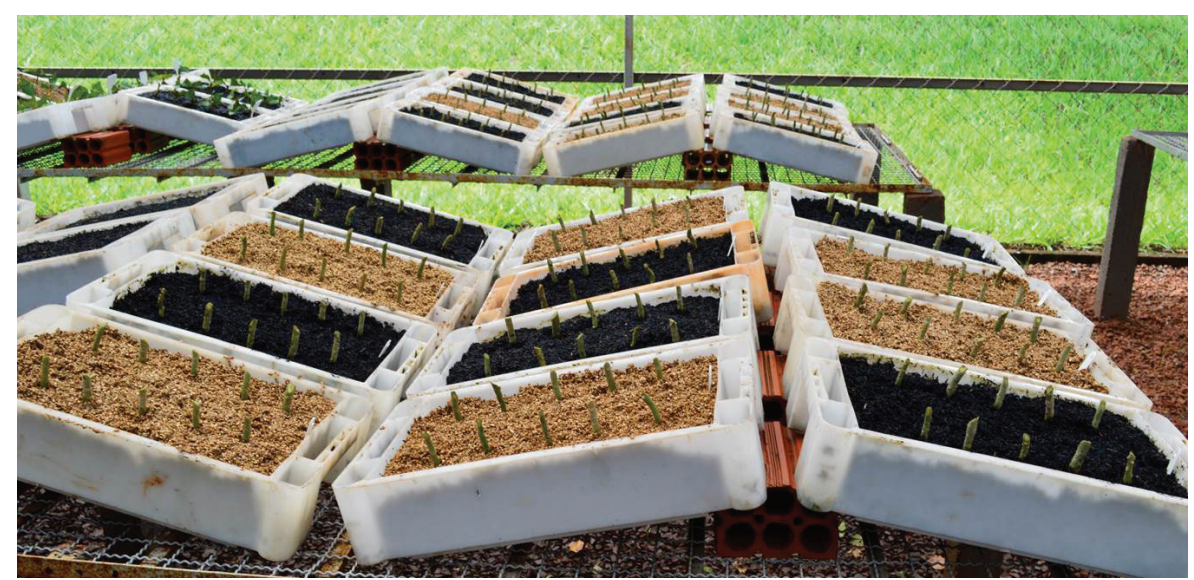

Figure 6. Hybrid Adenium cuttings submitted to rooting in carbonized rice husk bark and vermiculite, under the concentrations of 0 and $3000 \mathrm{mg} \mathrm{L}^{-1}$ of AIB diluted in talc. 
Studies related to Adenium propagation by cuttings are scarce. The available information is based on producer's observations and technical reports. The species propagation by cuttings has the advantage of obtaining plants genetically identical to the mother plant. However, seedlings propagated by cuttings may not be interesting, because they have less developed caudex compared to seedlings propagated by seeds; and the presence of welldeveloped caudex is an appreciated characteristic by consumers.

Although cuttings present high rooting potential, the use of auxins can be applied to optimize the rooting process. Tests performed at several periods with the propagation of two Adenium cultivars by cuttings, showed that the use of $8000 \mathrm{mg} \mathrm{L}^{-1}$ of indolebutyric acid (IBA) is suitable for apical cuttings rooting of the Ice Pink and Red cultivars. At some periods of the study, $100 \%$ rooting of the cuttings was observed in the absence of IBA (McBRIDE, 2012).

Regarding the substrates that can be used for the Adenium cuttings rooting, vermiculite, carbonized rice husk and semi-composted pine bark, among others, can be recommended. However, attention should be paid to irrigation management, since Adenium cuttings are susceptible to rot, due to their high water content.

\section{Grafting}

Adenium seedlings production by grafting has been outstanding in recent years, mainly, due to the consumer market demands for new varieties, such as folded flowers and new colors. Thus, grafting allows to produce seedlings of these highly segregated materials on rootstocks produced by seeds, which presents a swollen caudex, characteristic of the Adenium genus.

Seedlings aged from one year can already be used as rootstocks, since they have the caudex developed enough for grafting. Grafting on Adenium may be performed by the graft method or a method similar to the graft approach ('cork'). The grafting method may present a disadvantage, as uneven healing of the tissues in the graft region, while the 'cork' method presents uniform healing of this region, which becomes imperceptible after a few months of cultivation.

The 'cork' grafting method is described in the figure 7. The method consists of making a straight cut on the rootstock above the region where the caudex is most pronounced. The branch from the canopy variety to be grafted is cut into segments, similar to a small cork, with at least one vegetative bud. The union between the rootstock and the graft is by approaching grafts of the cut sides. To protect and better fix the graft, it is required to cover the area with plastic tape or other impermeable material (Figure 7A). After the graft initiates the emission of shoots, the plastic shall be removed, in order not to harm the shoot growth (Figures 7B).

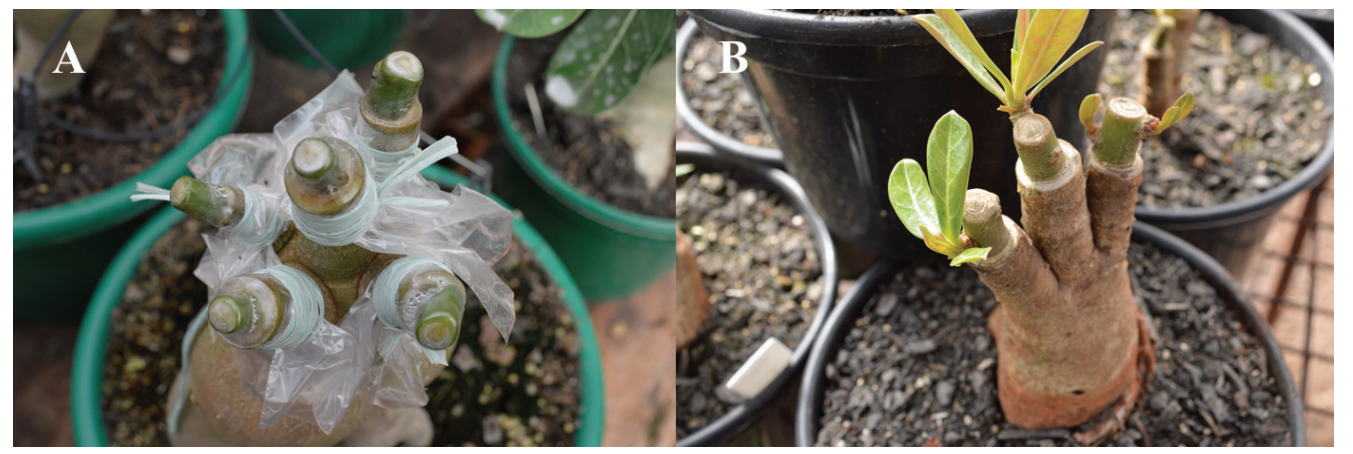

Figure 7. Graft protected with plastic, after the rootstock / canopy union (A) and graft emitting new shoots (B).

\section{In vitro propagation}

In vitro propagation is a viable alternative for the ornamental plants and their hybrids propagation in commercial scale. However, for Adenium, little is known about this subject, which may encourage new research aiming to establish protocols for Adenium in vitro propagation.

There are some satisfactory results presented in studies with the Adenium in vitro propagation. It has been verified that the establishment of the Adenium in vitro propagation came from the seed propagation, as shown by Kanchanapoom et al. (2010) and Rasad et al. (2015). However, seed propagation is not interesting to hybrids propagation and maintenance of their morphological characteristics.

When in vitro culture is established by seeds in culture media with auxin and cytokinin, callus formation in the explants is observed. Some of these calli differentiate into seedlings, but at low frequency (Figure 8). 


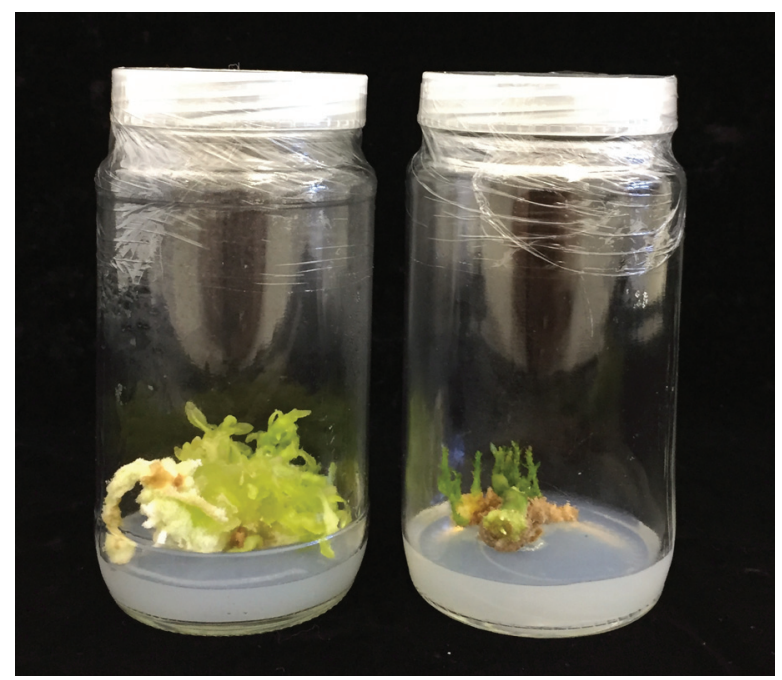

Figure 8. In vitro regeneration of Adenium obesum calli from seedlings culture.

Results obtained by in vitro culture using vegetative material, e.g. stems, leaves, are unknown to our knowledge. Initial trials with Adenium in vitro propagation using stem and leaf segments, the formation of callus was observed (data not shown), but there was not regeneration of shoots. In this sense, the need for more studies related to the Adenium in vitro propagation is crucial.

\section{ADENIUM GROWTH MANAGEMENT}

\section{Potting media and irrigation}

To produce potted ornamentals plants, it is available different types of potting media that can be used alone or mixed (GRUDA, 2012). However, to Adenium commercial production as potted plant, just a few studies are found regarding potting media and irrigation management (COLOMBO et al., 2018).

Plants grown in pots under greenhouse conditions are characterized by a high and unbalanced ratio between the plants canopy and the roots. These plants require greater water, air and nutrients than those grown directly in field conditions, where growth rates are slower and the volume of soil available for the roots is theoretically unlimited (GRUDA, 2012).

In view of these aspects, it is fundamental to choose a substrate that allows an adequate relation between water retention capacity and aeration. For Adenium cultivation, several materials can be used as substrate. In seedling production, substrates with low density and high aeration are recommended in order to avoid seed rotting. Among the recommended materials, substrates based on semicomposted pine bark, pure or in combination with coconut fiber, provide a high emergence percentage of seedlings, i.e. $97 \%$ and $98 \%$, respectively (COLOMBO et al., 2017).

According to the same authors, these substrates are also suitable for the initial development of Adenium seedlings, since these substrates provide greater initial nutrient input for plant growth. Similar results were presented by Alves et al. (2018), where the initial growth of Adenium was higher in substrate composed of sand:pine powder (1:1, $\mathrm{v} / \mathrm{v}$ ) associated with fertilization with Hoagland and Arnon solutions supplemented with $\mathrm{NH}_{3} \mathrm{NO}_{4}$.

Substrates based on semi-composted pine bark are widely employed by the producers and present satisfactory results in the growth and development of the species. The main characteristics of the substrates based on pine bark are the water retention capacity, great aeration space in relation to coconut fiber and it presents low density.

On the other hand, the coconut fiber substrate mixed with sand $(1: 1, \mathrm{v} / \mathrm{v})$ or vermiculite $(1: 1, \mathrm{v} / \mathrm{v})$, showed satisfactory initial growth in Adenium at 45 days after the seedlings transplanting and the absence of additional fertilization (COLOMBO et al., 2018). In the same study, it was verified that the effect of the mentioned substrates persisted during a period of seven months, similar to the substrate recommendation for Adenium commercial cultivation.

Physical analysis of the mix between vermiculite and coconut fiber $\left(1: 1, \mathrm{~V} \mathrm{v}^{-1}\right)$, showed that the mix presented low density $\left(136 \mathrm{~g} \mathrm{~L}^{-1}\right)$ and high water retention capacity (528 $\mathrm{mL} \mathrm{L}^{-1}$ ); these characteristics seem to be ideal to Adenium growth in pots (COLOMBO et al., 2016). Moreover, the low density of this substrate is an interesting characteristic to provide lighter pots, which facilitates their handling and transport.

Regarding the irrigation management, attention must be paid to the water supply required by the crop, despite its arid region origin, Adenium plants respond well to most constant irrigations. In a study carried out with Adenium cultivation on vermiculite and coconut fiber substrate $(1: 1$, $\left.\mathrm{v} \mathrm{v}^{-1}\right)$, the plants consumed about $10.7 \mathrm{~L}$ of water over a period of 210 days (COLOMBO et al. al. 2018). However, the water consumption is directly related to the substrate water retention capacity and the plant growth. For example, for vermiculite and pine bark $(1: 1, \mathrm{v} / \mathrm{v})$ substrate, in the same growing period, the plants consumed about $7.5 \mathrm{~L}$ of water, but presented a lower fresh mass compared to the plants grown in the vermiculite and coconut fiber substrate (COLOMBO, et al., 2018). 
Irrigation can be performed by sprinkler system or microtube drippers, being the last one more suitable as shoot wetting can harm flowering.

\section{Nutrition}

Despite being considered as a rustic plant, Adenium obesum presents a significant response to the fertilizers, which stimulate vegetative growth and anticipate flowering, accelerating the cultivation cycle of this species.

The crop cycle can be divided into three periods. The first, up to 100 days after seedling transplanting (DAT), is characterized by a slow growth, low dry matter accumulation and increase on plant height. The second period, from 100 to 200 DAT, begins with the development of secondary branches and extends until flowering, during this period there are increases in dry matter accumulation, initially in roots, leaves, branches and later in the caudex. The last period occurs after flowering, when the growth of roots, leaves and branches present a decrease.

During flowering, the nitrogen $(\mathrm{N})$, phosphorus $(\mathrm{P})$, and mainly potassium $(\mathrm{K})$ contents, decrease in the leaves, branches and caudex. The flowers are the main drains in this period, presenting average levels of $36 \mathrm{~g} \mathrm{~kg}^{-1}$ of $\mathrm{K}, 10$ $\mathrm{g} \mathrm{kg}^{-1}$ of $\mathrm{N}, 6 \mathrm{~g} \mathrm{~kg}^{-1}$ of calcium (Ca), $5 \mathrm{~g} \mathrm{~kg}^{-1}$ of $\mathrm{P}$ and $3 \mathrm{~g}$ $\mathrm{kg}^{-1}$ of magnesium $(\mathrm{Mg})$.

Among the nutrients, potassium is the most accumulated in the tissues, presenting content between 30 to $45 \mathrm{~g} \mathrm{~kg}^{-1}$; in which, caudex presents smaller values compared to leaves, branches and roots. The nutrient accumulation is followed by nitrogen and calcium. The calcium content range from 15 to $22 \mathrm{~g} \mathrm{~kg}^{-1}$ in leaves and branches, while caudex and roots present lower contents, ranging from 4 to $7 \mathrm{~g} \mathrm{~kg}^{-1}$ (COLOMBO et al., 2016; ALVES et al. al., 2018).

Nitrogen is observed in high concentration in leaves and branches, ranging from $10 \mathrm{~g} \mathrm{~kg}^{-1}$ on initial stages, reaching $15 \mathrm{~g} \mathrm{~kg}^{-1}$ in leaves to $25 \mathrm{~g} \mathrm{~kg}^{-1}$ in branches during the flowering period. In the roots, the nitrogen content is close to $12 \mathrm{~g} \mathrm{~kg}^{-1}$ until the beginning of secondary branches development. After this period, the root dry matter increases substantially, which reduces the nitrogen content between 6 to $9 \mathrm{~g} \mathrm{~kg}^{-1}$. In the caudex, the nitrogen content does not vary throughout the plant cycle, and it is similar to the roots level at the latter development stage.

The magnesium content for leaves, branches and roots vary from 4 to $5 \mathrm{~g} \mathrm{~kg}^{-1}$, and for the caudex presents between 2 and $3.5 \mathrm{~g} \mathrm{~kg}^{-1}$ for the whole cycle. The phosphorus level in tissues rise until the flowering period, starting from 1 to $2 \mathrm{~g} \mathrm{~kg}^{-1}$, reaching $3.5 \mathrm{~g} \mathrm{~kg}^{-1}$ in caudex and roots, $4 \mathrm{~g} \mathrm{~kg}^{-1}$ in branches, and $5 \mathrm{~g} \mathrm{~kg}^{-1}$ in leaves.

As in other crops, nitrogen gives the greatest response to $A$. obesum vegetative growth, in which nitric $\left(\mathrm{NO}_{3}\right)$ or ammonium $\left(\mathrm{NH}_{4}\right)$ supply can influence the fertilization efficiency. In this way, the $\mathrm{NO}_{3}: \mathrm{NH}_{4}$ ratio is an important parameter to nitrogen fertilization management, presenting an adequate ratio close to $1: 3\left(\mathrm{NO}_{3}: \mathrm{NH}_{4}\right)$ that provides superior growth and development to roots and caudex. In this way, urea becomes an important source of additional nitrogen due to its amine radical, easy accessibility and low cost.
Another issue that directly influences the efficiency of fertilization is the substrate choice, since it presents interaction to the fertilization. Plants fertilized with Hoagland and Arnon solution, supplemented with $590 \mathrm{mg}$ $\mathrm{L}^{-1}$ of nitrogen $\left(\mathrm{NO}_{3} \mathrm{NH}_{4}\right)$, when cultivated in sand and composed pine powder presented 4.0 and $1.6 \mathrm{~g}$ dry matter of caudex and leaves, respectively. On the other hand, the plants presented lower accumulation of dry matter in caudex and leaves (2.8 and $0.5 \mathrm{~g}$, respectively), using the same fertilization using sand and coconut fiber mixture (ALVES et al., 2018).

\section{DISEASE AND PEST}

Some diseases have been reported for this species, mainly caused by fungi and vira, as brown leaf spot, cucumber mosaic virus (CMV) and tomato spotted wild virus (TSWV).

The first report of brown leaf spot on A. obesum or any other member of the Apocynaceae family was described in 1995 by McMillan et al. (1997), caused by Aristastoma spp.. These authors isolated some known and unknown species of Aristastoma spp. from foliar lesions of $A$. obesum in a commercial nursery, where $100 \%$ of the crop was affected by these pests. According to the authors, the plant foliage presented irregular, oval to circular, rusty brown, and necrotic lesions from 5 to $15 \mathrm{~mm}$ in diameter.

In relation to viral diseases, Baker et al. (2003) firstly reported the CMV infection of $A$. obesum in Florida nurseries in 2002. Later, Chen et al. (2010) observed CMV infection in $A$. obesum plants occurring in Taiwan. The foliar symptoms are described as a mosaic with dark green islands surrounding the veins and chlorosis on the leaf margins.

Another virus that can damage this specie is the TSWV that was first reported in Europe in 1994 and Florida in 2004 (Adkins and Baker, 2005). The foliar symptoms include chlorotic ring and line patterns. According to Adkins and Baker (2005), attention to sanitation and insect vector management is required during the propagation and production as of the wide distribution of TSWV, the increasing popularity of $A$. obesum and the identification of CMV in this species.

For this specie, some insects as cochineals, aphids, caterpillar and thrips are the main pests. Neto et al. (2017) reported and described some of these organisms found in 2012 when investigating A. obesum used in landscaping in Goias-Brazil. These authors identified two species of cochineals, Hemiberlesia rapax Comstock (Hemiptera: Diaspididae) and Parasaissetia nigra Nietner (Hemiptera: Coccoidea); and one oleander aphid Aphis nerii Boyer (Hemiptera: Aphididae), damaging the leaves, flowers and stem of $A$. obesum. According to the authors, it was the first report of $H$. rapax occurring in $A$. obesum.

Besides cochineals and aphids, it was also reported the caterpillar Daphnis nerii Linnaeus (Lepidoptera: Sphingidae) occurring in A. obesum plants in Taiwan (LIN, 1997). However, to our knowledge, there was no available information to date about mite and thrips occurring on $A$. 
obesum, but these organisms are commonly found in some production area, where this specie is cultivated. When infested with mites, the $A$. obesum plants can present webs on the foliage and their leaves may appear scorched or bronzed, being able to shed the leaves. The A. obesum can also be infested by thrips, which drains the sap from the leaves and may experience dieback, wilt or leaf curling (personal communication - TAKEMURA, 2018).

\section{FLOWERING}

Adenium presents terminal inflorescences that arise from the apex of the branches. The inflorescences are the corymb type, presenting a varied number of flowers. The flowers open successively and remain opened for about seven days, if not irrigated directly on the petals, which can reduce the durability and quality of flowers (Figure 9).

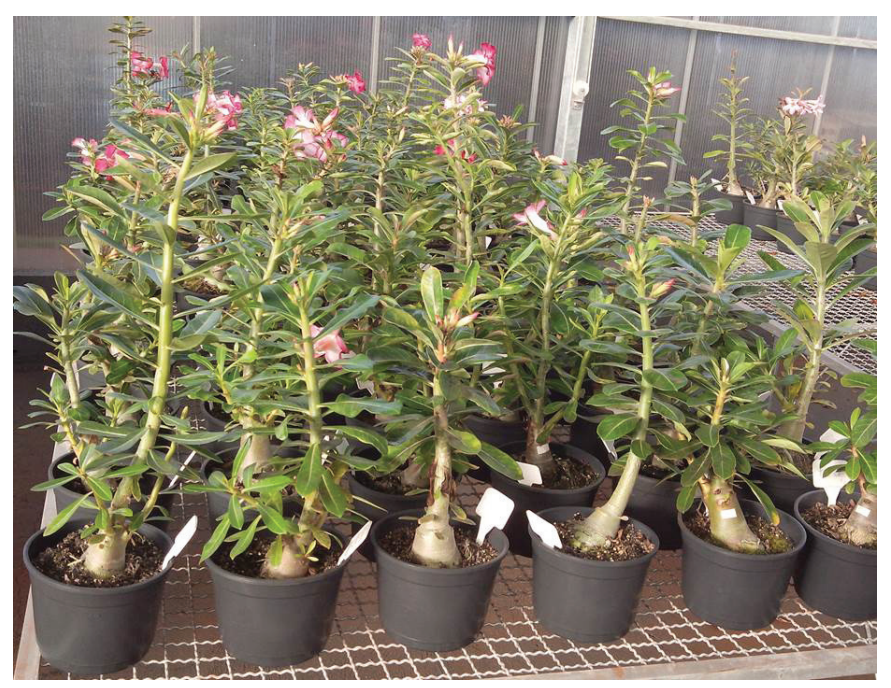

Figure 9. Commercial plants of Adenium obesum.

Adenium flowering can occur between seven to eight months after sowing, depending on the cultivation conditions (DIMMITT et al., 2009).

Irrigation management seems to influence the flowering period of this species, as plants grown on substrates of sand and coconut fiber $(1: 1, \mathrm{v} / \mathrm{v})$ and vermiculite and coconut fiber $(1: 1, \mathrm{v} / \mathrm{v})$ using water retention capacity between $60 \%$ and $70 \%$, indicated earlier flowering compared to plants kept on the same substrate, but using higher water availability (COLOMBO et al., 2018).

In Brazil, the species can flourish year-round, except in regions with lower temperatures, such as the Southern region. In these regions, it is also common to observe the leaves falling during the coldest period, and in early spring, the inflorescences and new leaves start to appear.

\section{COMMERCIALIZATION}

The commercialization of Adenium in Brazil, until few years ago, was carried out in an informal way, in which one could acquire flowering plants from small producers, or even acquire young seedlings, without being certain of the color and shape of the flowers, due to the high genetic variability found in the species.

Nowadays, this market has been organized and it is being possible to acquire plants in flower shops and supermarkets, such as traditional potted plants, with an affordable price. It is common to find flowering plants of two and three years, but it is also common to find older plants in some specialized florists, presenting the most developed and sculptural caudex.

\section{FINAL CONSIDERATIONS}

Adenium plants have substantial ornamental potential as a potted plant due to its peculiar and sculptural forms, associated to exuberant flowering with flowers of different shapes and colors.

Regarding the seedlings production, there is a market gap for seed production and multiplication of hybrid materials. The establishment of in vitro propagation protocols of this species presents as an opportunity to new research.

The commercial cultivation of this specie is not yet well established in Brazil. There is a lack on scientific information about crop management and production uniformity. Another challenge is the development of plant classification standards, aiming to establish a pricing system, since the plant price suffers a lot of regional variation.

\section{AUTHORS CONTRIBUTIONS}

R.C.C.: Creation of the idea and manuscript preparation. M.A.C.: Manuscript preparation. D.U.C.: Manuscript preparation. R.T.H.: Manuscript preparation. G.A.C.A.: Manuscript preparation. R.T.F.: Orientation of the work and important suggestions incorporated to the work. 


\section{REFERENCES}

ADKINS, S.; BAKER, C.A. Tomato spotted wilt virus identified in desert rose in Florida. Plant Disease, v.89, n.5, p.526, 2005. DOI: https://doi.org/10.1094/PD-89-0526C

ALVES, G.A.C.; HOSHINO, R.T.; BERTONCELLI, D.J.; SUZUKI, A.B.P.; COLOMBO, R.C.; FARIA, R.T. Substrates and fertilizations in the initial growth of the desert rose. Ornamental Horticulture, v.24, n.1, p.19-27, 2018. DOI: http://dx.doi.org/10.14295/oh.v24i1.998

BAKER, C.A.; ACHOR, D.; ADKINS, S. Cucumber mosaic virus diagnosed in desert rose in Florida. Plant Disease, v.87, n.8, p.1007, 2003. DOI: https://doi. org/10.1094/PDIS.2003.87.8.1007C

CHEN, Y.K.; CHANG, Y.S.; LIN, Y.W.; WU, M.Y. First report of cucumber mosaic virus in desert rose in Taiwan. Plant Disease, v.96, n.4, p.593, 2012. DOI: https://doi. org/10.1094/PDIS-11-11-0917

COLOMBO, R.C.; FAVETTA, V.; CARVALHO, D.U.; CRUZ, M.A.; ROBERTO, S.R.; FARIA, R.T. Production of desert rose seedlings in different potting media. Ornamental Horticulture, v.23, n.3, p.250-256, 2017. DOI: http://dx.doi.org/10.14295/oh.v23i3.1039

COLOMBO, R.C.; FAVETTA, V.; MELO, T.R.; FARIA, R.T.; SILVA, M.A.A. Potting media, growth and build-up of nutrients in container-grown desert rose. Australian Journal of Crop Science, v.10, n.2, p.258-263, 2016.

COLOMBO, R.C.; FAVETTA, V.; SILVA, M.A.A.; FARIA, R.T. Substrates and irrigation levels for growing desert rose in pots. Ciência e Agrotecnologia, v.42, n. 1, p.69-79, 2018. DOI: http://dx.doi.org/10.1590/1413-70542018421002117

COLOMBO, R.C.; FAVETTA, V.; YAMAMOTO, L.Y.; ALVES, G.A.C.; ABATI, J.; TAKAHASHI, L.S.A.; FARIA, R.T. Biometric description of fruits and seeds, germination and imbibition pattern of desert rose [Adenium obesum (Forssk.), Roem. \& Schult.]. Journal of Seed Science, v.37, n.4, p.206-213, 2015. DOI: http://dx.doi. org/10.1590/2317-1545v37n4152811

DIMMITT, M.; JOSEPH, G.; PALZKILL, D. Adenium: Sculptural Elegance, Floral Extravagance. Tucson: Scathingly Brilliant Idea, 2009. 152p.
FORSTER, P.I. Correct names for some cultivated species of Adenium (Apocynaceae). Cactus and Succulent Journal, v.70, n.4, p.199-200, 1998.

GRUDA, N. Sustainable peat alternative growing media. Acta Horticulturae, v.927, p.973-979, 2012. DOI: 10.17660/ActaHortic.2012.927.120

HARGREAVES, B.J. How many species of Adenium are there? Asklepios, v.85, p.23, 2002.

KANCHANAPOOM, K.; SUNHEEM, S.; KANCHANAPOOM, K. In vitro propagation of Adenium obesum (Forssk.) Roem. and Schult. Notulae Botanicae Horti Agrobotanici Cluj-Napoca, v.38, n.3, p.209-213, 2010. DOI: http://dx.doi.org/10.15835/nbha3834604

LIN, C.S. Larval morphology and life history of eight sphingid species in Taiwan. Journal of the Taiwan Museum. v.50, p.67-76, 1997.

McBRIDE, K. M. The effect of cultural practices on growth, flowering, and rooting of Adenium obesum. 2012. 116 f. Thesis, University of Florida, 2012.

Mclaughlin, J.; GAROFAlO. J. The Desert Rose, Adenium obesum: Nursery Production. Homestead: Miami-Dade, 2002. 2p. (Boletim 66).

McMILLAN, R.T.; GRAVES, W.R.; LEAHY, R.M. First report of Aristastoma leaf spot on desert rose. Plant Disease, v.81, n.8. p.960, 1997. DOI: https://doi. org/10.1094/PDIS.1997.81.8.960D

NETO, L.J.T.; RODRIGUES, O.D.; TSAI, H.M.; ESTEVAM, J.T.; PEREIRA, J.M.; SELEGUINI, A. Ocorrência de insetos fitófagos em Adenium obesum (Forssk.) Roem. \& Schult no estado de Goiás. Revista Agro@mbiente, v.11, n.4, p.379-384, 2017. DOI: https:// doi.org/10.18227/1982-8470ragro.v11i4.4222

PLAIZIER, A.C. A revision of Adenium Roem. \& Schult. and of Diplorhynchus Welw. ex Fic. \& Hiern (Apocynaceae). Mededelingen Landbouwhogeschool, v.80, n.12, p.1-40, 1980.

RASAD, F.M.; HASBULLAH, N.A.; DAUD, N.F.; AZIS, N.A.; AMIN, M.A.M.; LASSIM, M.M. Micropropagation of Adenium obesum (Dessert Rose) in vitro. International Conference on Agricultural, Ecological and Medical Sciences (AEMS-2015) Phuket, Thailand, p. 10-12, 2015. 